\title{
Erratum to: Human motion recognition using a wireless sensor-based wearable system
}

\author{
John Paul Varkey • Dario Pompili •
}

Theodore A. Walls

Published online: 14 August 2012

(C) Springer-Verlag London Limited 2012

\section{Erratum to: Pers Ubiquit Comput}

DOI 10.1007/s00779-011-0455-4

In the original publication, the below acknowledgment was unfortunately missed:

Acknowledgments The authors would like to thank Rutgers undergraduate student Alex Weiner for helping fine-tune the proposed classification algorithm used for human motion recognition.

The online version of the original article can be found under doi:10.1007/s00779-011-0455-4.

J. P. Varkey · D. Pompili ( $₫)$

Department of Electrical and Computer Engineering,

Rutgers University, New Brunswick, NJ, USA

e-mail: pompili@ece.rutgers.edu

J. P. Varkey

e-mail: johnpaul_varkey@cac.rutgers.edu

T. A. Walls

Department of Psychology,

University of Rhode Island, Kingston, RI, USA

e-mail: walls@uri.edu 